\title{
山羊を用いた飼養試験および出納試験による蒸募処理ブナと 蒸煮処理コナラの栄養価評価
}

\author{
石田元彦・寺田文典・久馬 忠・滝川明宏 ${ }^{*}$ \\ 長沢定男 ${ }^{* *} \cdot$ 志水一允 ${ }^{* *}$ \\ 農林水産省畜産試験場，茨城県筑波農林研究団地 305 \\ ** 農林水産省森林総合研究所, 茨城県筑波農林研究団地 305
}

(1989. 7. 17 受付)

\begin{abstract}
要 約 $17 \mathrm{~kg} / \mathrm{cm}^{2}$ で 15 分間蒸炭処理したブナとコナラの栄養伍を，子山羊を用いた飼養試験之出 納試験を実施して検討した１１）イタリアンライグラス（IRG）乾草を $48 \%$ (飼料乾物中）含む飼料, 2）蒸著処理ブナを $45 \%$ 含む飼料，および 3 ）蒸煮処理コナラを $47 \%$ 含む飼料を給与する 3 処理区を 設けた。 日本在来種去勢雄山羊 12 頭（試験開始時，平均 22 週秢，平均体重 $11.0 \mathrm{~kg}$ ）を用い，1区あ たり 4 頭ずつ割り当てて，飼養試験を夷施した．飼料の給与は，どの山羊にも代謝体重あたり等量の制 限給慨とした．飼養試験に引き続き，全筫尿採取による出納試験を実施した，その結果, 飼養試験期間 中の乾物摄取量，1日増体量および飼料要求率について，3区の間に有意な差は認められなかった、消 化試験成縝から，間接法で求めた可消化養分総量の含量（乾物中）は，IRG 乾草が $54 \%$, 蒸煮処理フ ナが $43 \%$ ，蒸煮処理コナラが $47 \%$ であった，以上の結果から，蒸惹処理ブナ上蒸惹処理コナラは，反 鴐動物によってエネルギー源として利用され，蒸煮処理ブナは稲わら，蒸惹処理コナラは野草類に相当 するエネルギー価を有すると判断された。
\end{abstract}

日畜会報, $61(2): 150-156,1990$

木材は，そのままでは反稂家音によってほとんど消化 されない，しかし，木材は蒸薏処理によって消化率が高 められ $5^{2-6)}$ 上シラカンバ7-10) を反努家畜の飼料として利用す る研究が行なわれている。 また，滝川ら (末発表)は, 蒸㟟処理したブナとコナラの山羊による有機物消化率か 45\%から $49 \%$ であることを見い出しており，それらが 反妿家畜の飼料として活用できることが示唆される，し 汃, 蒸煮処理したブナやコナラがエネルギー源として 家畜によって利用されるのかどうかは，飼養試験を行な って確める必要がある.

本報告では，蒸煮処理したブナとコナラの栄養価を明 加にするために，山羊を用いて飼養試験と出納試験を実 施した.

\section{材料および方法}

1）供試動物：農林水産省畜産試験場（畜試）で生産

* 現所属: 農林水産省北海道農業試験場, 札幌市 004

日畜会報，61（2）：150-156

された日本在来種去勢雄子山羊 12 頭（平均 22 週齢，平 均体重 $11.0 \mathrm{~kg}$ ）を供試した。

2）給与飼料：供試した蒸薏処理フナと蒸煮処理コナ ラは, 農林水産省林業試験場 (現在, 森林総合研究所) で、剥皮したブナとコナラのチップを $17 \mathrm{~kg} / \mathrm{cm}^{2} て ゙ 15$ 分間蒸劣した後， $20 \mathrm{~mm}$ のふるいを装着したカッター ミルで粋研したものであった．対照区の飼料として用い たイタリアンライグラス（IRG）乾草は，音試で生産 された 2 番草, 開花期のあので，ウエハー状に成型，加 エされたものをはぐしたものであった。

IRG 乾草，蒸若処理ブナまたは蒸萫処理コナラを濃 厚飼料と表 1 に示す割合で配合して，3 種類の給与飼料 を調製した。これら 3 種類の給与飼料の可消化養分総量 (TDN) と可消化粗蛋白質 (DCP) の含量は，ほぼ等 しくなるように設計した。

この場合，日本在来種山羊が良好な発育をするために は, 給与飼料の DCP 含量を $10 \%$ 以上にする必要があ る ${ }^{11)}$ ので，各区の給与飼料の DCP 含量は $12 \%$ に設定 
Table 1. Ingredient composition and predicted nutritive value of the diets containing Italian ryegrass hay, steamed Japanese beech and steamed Japanese oak

(DM\%)

\begin{tabular}{|c|c|c|c|}
\hline \multirow{2}{*}{ Items } & \multicolumn{3}{|c|}{ Treatment } \\
\hline & $\mathrm{IRG}^{\prime \prime}$ & Beech ${ }^{21}$ & $\mathrm{Oak}^{31}$ \\
\hline \multicolumn{4}{|l|}{ Ingredient composition } \\
\hline Italian ryegrass hay & 48.18 & - & - \\
\hline Steamed Japanese beech & - & 44.90 & - \\
\hline Steamed Japanese oak & - & - & 47.39 \\
\hline Ground corn & 21.76 & 35.66 & 17.87 \\
\hline Soybean meal & 6.77 & 4.85 & 7.78 \\
\hline Soybean casein ${ }^{4 !}$ & - & 7.15 & 4.09 \\
\hline Wheat bran & 21.77 & 4.95 & 20.85 \\
\hline $\mathrm{CaCO}_{3}$ & 1.49 & 0.99 & 1.50 \\
\hline $\mathrm{CaHPO}_{4}$ & - & 1.17 & 0.49 \\
\hline $\mathrm{KCl}$ & - & 0.30 & - \\
\hline Vitamin mixture ${ }^{5)}$ & 0.03 & 0.03 & 0.03 \\
\hline \multicolumn{4}{|l|}{ Predicted nutritive value } \\
\hline $\mathrm{DCP}^{(1)}$ & 11.5 & 11.7 & 11.6 \\
\hline $\mathrm{TDN}^{71}$ & 69.1 & 69.7 & 69.3 \\
\hline
\end{tabular}

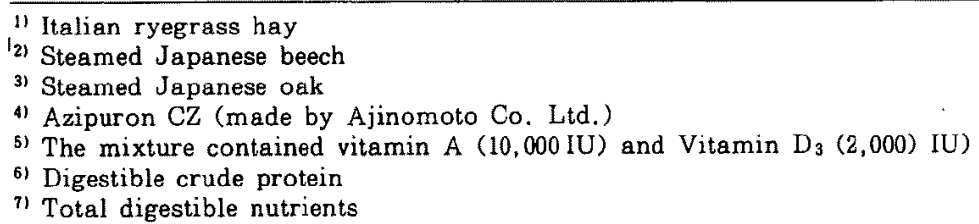

した、また，本実験では，牛の実験動物上して山羊を用 いたので, 給与飼料の TDN 含量は, 肥育中の乳用種 去勢牛の給与飼料に必要な咅分含量（日本飼荃標準，肉 用牛，(1987 年版 $\left.)^{12}\right)$ を参考にして，約 $70 \%$ とした。 IRG 乾草の DCP 含量は粗蛋白質 (CP) 含量をケル ダール法 ${ }^{13)}$ で求め, $\mathrm{DCP}=-3.5+0.924 \mathrm{CP}$ の式 ${ }^{14)}$ 用いて推定し，蒸募処理ブナと蒸煮処理コナラの DCP 含量は蒸煮処理シラカンバと同じくゼロとしだ． IRG 乾草の TDN 含量は, 阿部・堀井の方法 ${ }^{15)}$ で推定した. 蒸募処理ブナと蒸薏処理コナラのTDN 含量は, 飼料 をセルラーゼで消化する滝川らの方法 (未発表) で推定 した．粉砕トウモロコシ，大豆粕およびフスマの DCP と TDN の含量虹常法 ${ }^{13)}$ により一般成分組成を测定し， 消化率を日本標準飼料成分表 $\left(1987\right.$ 年版 ${ }^{16)}$ より引用し て算出した，大豆抽出蛋白質（アジプロン CZ，味の素 株式会社製）については，一般成分組成 ${ }^{13)}$ を求めて， その粗蛋白質含量に大豆粕の粗蛋白質の消化率 ${ }^{16)}$ を乗 じこれを DCP とTDN の含量とした。

3）飼養試験：供試山羊を平均体重がほぼ等しくなる ように, 4 頭ずっ 3 群にわけ，IRG 乾草, 蒸者処理ブ ナまたは蒸著処理コナラ主体の飼料（表1）の3好理区 に割り当てた，予備期 7 日間の後，70日間本試験を奏 施した。山羊は， $75 \mathrm{~cm} \times 160 \mathrm{~cm}$ の金網休のペンで単
飼した．飼料給与量は，各区とも山羊の代謝体重あたり 等量とし，週每に潪增させた．水とミネラルブロックは 自由摄取させた。本試験の期間中， 1 週間に 1 回，体重 と残飼の量を測定し，1 日当りの飼料摄取量と増体量を 求めた。

4）消化試験と窒素出納試験：飼養試験の終了後，消 化試験で用いた山羊を供試して，消化試験と坴素出納試 験を㬰施し，3処理区の給与飼料の栄養価扰よび IRG 乾草, 蒸煮処理ブナと蒸煮処理コナラの TDN 含量を 求めた。山羊を $20^{\circ} \mathrm{C}$ の調温実験空の代謝ヶージへ移し, 約 7 日間の馴致の後，予備期と本試験をそれぞれ7日間 設定し，本試験の期間中，全霬尿を採取した ${ }^{13\rangle}$ ．尿の採 取は田野らの方法 ${ }^{17)}$ に従った。飼料の乾物給与量は， 各区とも山羊の代謝体重あたり $45 \mathrm{~g}$ とし，水とミネラ ルブロックは自由捸取とした。

供試飼料および採取䔬は， $60^{\circ} \mathrm{C}$ の通風乾燥器で乾燥 後，風乾物としたものをウィレー式粉砕器で粉砕した後， $1 \mathrm{~mm}$ の標準フルイにかけ，フルイを通らなかったも のは $0.5 \mathrm{~mm}$ のフルイを付けた超遠心式粉砕機（三田 村理研工業株式会社製) で㸮砕し，すべての試料が 1 $\mathrm{mm}$ の標準フルイを通るようにして，分析用試料を調 製した。飼料之翼の一般成分組成 ${ }^{13)}$ を測定し，給与飼 料のみかけの消化率と DCP および TDN の含量を求 
めた。

IRG 乾草，蒸者処理ブナおよび蒸薏処理コナラの TDN 含量は，給与飼料全体の TDN 含量と給与飼料 に配合した濃厚飼料のTDN 含量の推定值を用いて, 間接法 ${ }^{16)}$ により算出した。濃厚眗料のTDN 含量の推 定法は，前述した通りであった

採取した尿の率菜含量をケルダール法 ${ }^{13)}$ で测定して， 跮素出納を求めた。

5）統計好理 : 得られたデータを分散分析して，給与
飼料の効果の有意性と区間の平均值の差を検定した ${ }^{18)}$.

$$
\text { 結果 }
$$

IRG 乾草, 蒸薏処理ブナおよび蒸㟟処理コナラの 般成分組成と栄養価の推定值は，表 2 に示すとおりであ った.

蒸薏姏理ブナと蒸㟟処理コナラは，IRG 乾草に比べ て，粗蛋白質と粗灰分の含量がかなり低く，可溶無窑索 物と粗紻維の含量が高かった。

Table 2. Chemical composition of Italian ryegrass hay, steamed Japanese beech and steamed Japanese oak

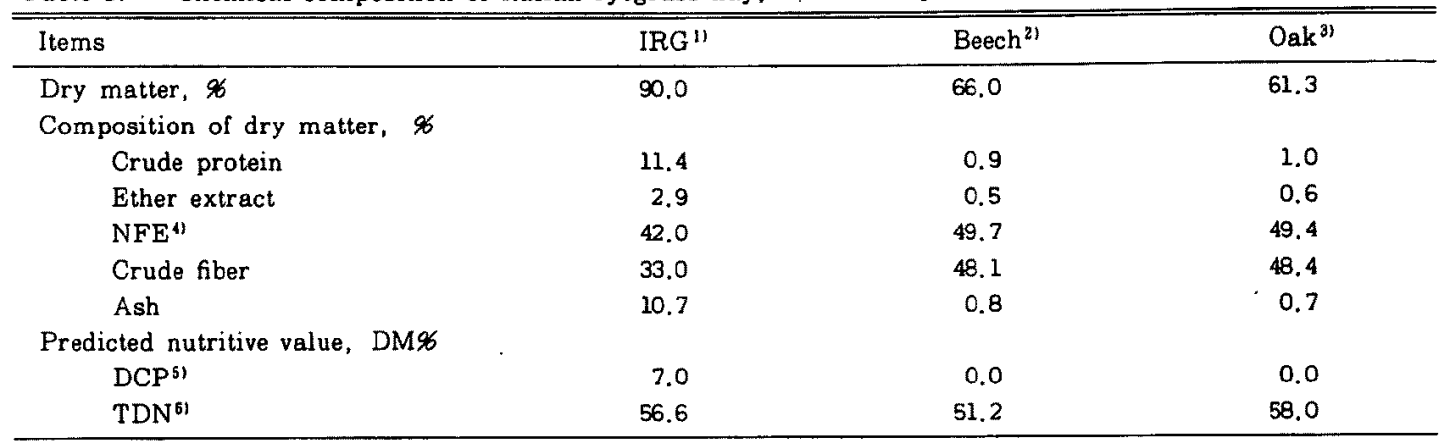

$11,21,31$ are same as in table 1

4) Nitrogen free extracts

5) Digestible crude protein

6) Total digestible nutrients

Table 3. Chemical composition, apparent digestibility and nutritive value of the diets containing Italian ryegrass hay, steamed Japanese beech and steamed Japanese oak

\begin{tabular}{|c|c|c|c|}
\hline \multirow{2}{*}{ Items } & \multicolumn{3}{|c|}{ Treatment } \\
\hline & IRG" & Beech $^{2)}$ & Oak ${ }^{31}$ \\
\hline \multicolumn{4}{|l|}{ Chemical composition, DM\% } \\
\hline Crude protein & 15.3 & 13.8 & 14.0 \\
\hline Ether extract & 3.6 & 2.2 & 2.3 \\
\hline NFE') & 53.3 & 56.7 & 53.2 \\
\hline Crude fiber & 19.0 & 23.1 & 25.8 \\
\hline Ash & 8.7 & 4.3 & 4.6 \\
\hline \multicolumn{4}{|l|}{ Apparent digestibility, $\mathscr{6}$} \\
\hline Number of animals & 4 & 3 & 4 \\
\hline Crude protein & $75.6 \pm 0.6^{51}$ & $73.1 \pm 1.3$ & $75.5 \pm 1.6$ \\
\hline Ether extract & $83.3^{b} \pm 1.0$ & $88.4^{2} \pm 2.1$ & $87.3^{\bullet} \pm 0.6$ \\
\hline $\mathrm{NFE}$ & $74.1 * \pm 1.8$ & $69.9^{\circ} \pm 0.5$ & $66.4^{\mathrm{c}} \pm 2.0$ \\
\hline Crude fiber & $52.7 \pm 3.5$ & $53.0 \pm 0.4$ & $52.7 \pm 4.3$ \\
\hline \multicolumn{4}{|l|}{ Nutritive value, DM\% } \\
\hline $\mathrm{DCP}{ }^{6)}$ & $11.6^{2}$ & $10.1^{\mathrm{c}}$ & $10.6^{6}$ \\
\hline $\mathrm{TDN}^{n}$ & $68.0^{*}$ & $66.2^{\mathrm{ab}}$ & $64.1^{\mathrm{b}}$ \\
\hline
\end{tabular}

$11,21,3)$ are same as in table 1

"Nitrogen free extracts

5) Mean \pm standard deviation

6) Digestible crude protein

$n$ Total digestible nutrients

$a, b, c$ Means in the same row with different superscripts differ $(p<0.05)$. 
給与飼料の一般成分組成，みかけの消化率および栄養 価は表 3 に示すとおりであった。

出納試験では，ブナ区の 1 頭が代謝ケージの飼槽に入 る悪癖がついたために，粪尿の採取が出来なくなった． そのために，その山羊からデー夕を得ることが出来なか った，DCP の含量について，区閒に有意な差が認めら れたが，その差は1-1.5\%程度で大きくはなかった。

TDN 含量は，コナラ区が IRG 区よりも4\%低かった。

間接法で求めた TDN 含量は表 4 に示すとおりであ った。

蒸煮処理コナラと IRG 乾草の TDN 含量には有意 な差はなかったが，蒸著処理ブナの TDN 含量は IRG 乾草および蒸者処理コナラよりも有意に低かった。

1日あたりの蓄積窒素量，摄取または吸収された窒素 の蓄積割合については，区間に有意な差がなかった（表 $5)$.

山羊の体重は, 飼養試験の進行とともに直線的に增加 し, 体重 $(\mathrm{Y})$ と武験期間 (週, $\mathrm{X}$ ) との間の回帰式は, IRG 区で, $\mathrm{Y}=11.3+0.47 \mathrm{X}(\mathrm{P}<0.05) ;$ ブナ区で, $\mathrm{Y}=10.6+0.48 \mathrm{X}(\mathrm{P}<0.05) ;$ コナラ区で, $\mathrm{Y}=10.6+$ $0.45 \mathrm{X}(\mathrm{P}<0.05)$ であった.

表 6 に䝭養試験成績を示す. 3 つの処理区の 1 日増体
量と乾物攖取量には有意な差はなかった，ただ，コナラ 区の 1 日增体量はIRG区よりも低い傾向にあり， TDN 摄取量についてもコナラ区が IRG 区よりむ有意 に低加った。羊は TDN 摄取量の 30-39\%を IRG 乾草，蒸煮処理ブナまたは蒸募処理コナラから摄取した。 山羊が $1 \mathrm{~g}$ 堌休するのに要した乾物，DCP および TDN の量については，3処理区の間に有意な差はなかった。

\section{考察}

本実験の結果，ブナ区とコナラ区の 1 日増体量は IRG 区と変わらず，また，ブナとコナラ区の山羊は IRG 区の山羊と同様に試験の進行につれて直線的に增体した。 これらのことから、ブナ区とコナラ区の山羊か順調に発 育したものと考えられた．また，TDN 摄取量に占める 蒸著処理木材からの TDN が占める割合は, ブナ区で 30 \%,コナラ区で $35 \%$ であったことを考え合わせると， 蒸者処理ブナと蒸㟟好理コナラは反独家畜のエネルギー 源として十分に利用できると考えられた。

一方, 消化試験で求めた蒸募処理ブナと蒸堂処理コナ ラの TDN 含量は，それぞれ乾物中 $43 \%$ と $47 \%$ であ った，これらのTDN 含量を日本標準飼料成分表 ${ }^{16)}$ に 記載されている飼料のTDN 含量と比較すると，蒸㝸

Table 4. Total digestible nutrients content, calculated by difference,

in Italian ryegrass, steamed Japanese beech and steamed Japanese oak

\begin{tabular}{lccc}
\hline \hline Items & IRG $^{11}$ & Beech $^{21}$ & Oak $^{31}$ \\
\hline Number of animals, head & 4 & 3 & 4 \\
TDN & $44.3^{\mathrm{a}} \pm 3.2^{51}$ & $43.4^{\mathrm{b}} \pm 1.0$ & $46.9^{\mathrm{a}} \pm 4.6$ \\
\hline
\end{tabular}

$1,21,3)$ are same as in table 1

4) Total digestible nutrients

5) Meantstandard deviation

" Means in the same row with different superscripts differ $(p<0.05)$

Table 5. Utilization of nitrogen in the goats fed the diets containing Italian ryegrass hay, steamed Japanese beech and steamed Japanese oak

\begin{tabular}{lccc}
\hline \hline \multirow{2}{*}{ Items } & \multicolumn{2}{c}{ Treatment } \\
\cline { 3 - 4 } & IRG $^{11}$ & Beech $^{21}$ & Oak $^{31}$ \\
\hline $\begin{array}{l}\text { Number of animal } \\
\text { Nitrogen intake, g/day }\end{array}$ & 4 & 3 & 4 \\
Nitrogen excretion, g/day & $8.4 \pm 1.0^{41}$ & $7.4 \pm 1.0$ & $7.4 \pm 0.4$ \\
$\quad$ Fecal & $2.0 \pm 0.2$ & & \\
$\quad$ Urinary & $5.3 \pm 0.6$ & $4.0 \pm 0.3$ & $1.8 \pm 0.1$ \\
Nitrogen retention & & $4.6 \pm 0.2$ \\
$\quad$ Gram per day & $1.1 \pm 0.2$ & $1.1 \pm 0.3$ & $1.0 \pm 0.3$ \\
$\quad$ Percent of nitrogen intake & $12.6 \pm 1.3$ & $11.3 \pm 4.0$ & $13.8 \pm 4.1$ \\
$\quad$ Percent of absorbed nitrogen & $16.7 \pm 1.6$ & $23.8 \pm 8.8$ & $18.2 \pm 5.0$ \\
\hline
\end{tabular}

$11,21,3)$ are same as in table 1

4) Mean tstandard deviation 
石田・寺田・久馬・滰川・長沢・志水

Table 6. Body weight gain, feed intake and feed conversion in the goats fed the diets containing Italian ryegrass hay, steamed Japanese beech and steamed Japanese oak

\begin{tabular}{|c|c|c|c|c|}
\hline \multirow{2}{*}{ Items } & \multicolumn{3}{|c|}{ Treatment } & \multirow{2}{*}{$\begin{array}{l}\text { Standard } \\
\text { error }\end{array}$} \\
\hline & IRG $^{11}$ & Beech ${ }^{2)}$ & Oak $^{31}$ & \\
\hline Number of animals & 4 & 4 & 4 & - \\
\hline Initial weight, $\mathrm{kg}$ & 11.3 & 10.8 & 10.8 & 1,0 \\
\hline Daily gain, g/day & 68.0 & 68,8 & 61.6 & 2.7 \\
\hline \multicolumn{5}{|c|}{ Feed intake, g/day/MBS ${ }^{4}$ ? } \\
\hline Dry matter & 68.2 & 68.0 & 67.6 & 0.1 \\
\hline $\mathrm{DCP}^{51}$ & $7.9^{\mathrm{s}}$ & $6.8^{\mathrm{c}}$ & $7.1^{\mathrm{b}}$ & 0.0 \\
\hline \multirow[t]{2}{*}{$\operatorname{TDN}^{61}$} & $46.3^{a}$ & $45.1^{\mathrm{ab}}$ & $43.2^{6}$ & 0.1 \\
\hline & $\left(38.6^{a}\right)^{n}$ & $\left(29.6^{c}\right)$ & $\left(34.9^{b}\right)$ & $(0.8)$ \\
\hline \multicolumn{5}{|c|}{ Feed conversion (Feed/Gain) } \\
\hline Dry matter & 7.1 & 6.8 & 7.5 & 0.4 \\
\hline $\mathrm{DCP}^{51}$ & 0.8 & 0.7 & 0.8 & 0.0 \\
\hline $\operatorname{TDN}^{61}$ & 4.8 & 4.5 & 4.8 & 0.2 \\
\hline
\end{tabular}

$11,21,3$ are same as in table 1

4) Metabolic body size, $W^{0.75} \mathrm{~kg}$

5) Digestible crude protein

6) Total digestible nutrients

7) Values in parenthesis were percentage of TDN intake derived from Italian ryegrass, steamed Japanese beech or steamed Japanese oak in total TDN intake

$a, b, c$ Means in the same row with different superscripts differ $(p<0,05)$

処理ブナは稻わら，蒸素処理コナラは野乾草に相当する 飼料エネルギー価を有すると判断された。

飼料要求率は，飼料エネルギーの摄取量が高いはど改

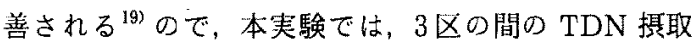
量がほぼ等しくなるように配慮して実験を行なった。 の結果, ブナ区は, TDN 摄取量, 飼料要求率とも IRG 区と有意の差はなかった。しかし，蒸黄処理コナラの TDN 含量の推定值（表 2）が実測值（表 4)よりも 11 \%䯩かったために，コナラ区の給与飼料の TDN 含 量が設計值よりも低くなり，その結果，コナラ区の TDN 捸取量が IRG 区上りも有意に低くなった（丧 6). しかし，飼料要求率は飼料エネルギ一の摄取虫が高い程 改善されることおよび IRG区よりすTDN 搨取量の 低かったコナラ区の飼料要求率が IRG 区と変わらなか ったことから、コナラ区のエネルギーの利用性が IRG 区よりあ少るとは考えられなかった，蒸㟟処理材材には， へミセルロースが䳆煮処理によって，分解されて生成す るフルフラールが含まれることが報告されている201 その他にリグニンの分解産物など，従柬の飼料には含ま れていない成分が含まれることが予想される，そのため に，蒸煮処理木材を給与することで，給与飼料の利用性

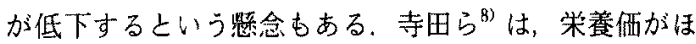
ぼ等しくなるように調製した蒸乽好理シラカンバを飼料 乾物中 $60 \%$ 含んだ飼料とアルファルファヘイキューブ を $69 \%$ 含んだ飼料を山羊に等量給与して增体量を比较
したしころ，蒸薏好理シラカンバを配合された飼料を給 与された山羊の増体量の方が低かった上報告している。

しかし，表60飼料要求率の結果からは，給与飼料の 45 $\%$ 以下であれば， $17 \mathrm{~kg} / \mathrm{cm}^{2}$ で 15 分間蒸意処理したブ ナやコナラを飼料に配合してあ，給与飼料全体の利用性 に悪い影響を及ぼさないと考えられた。

以上のことから，蒸者処理ブナと蒸煮処理コナラは反 知家畜によってエネルギー源として利用され，それらを 給与飼料の $45 \%$ まで配合しても，家畜による飼料の利 用性に悪影響を及ぼさない上考えられた。しかし，表 2 に示したように，蒸者処理したブナとコナラには粗蛋白 質上ミネラルがほ上んど含まれていない，蒸㟟処理ブナ や蒸薏好理コナラを飼料に配合する場合には，これらの 栄養素が不足することのないように十分配虑する必要が ある。また，蒸惹処理木材の粗飼料因子の給源としての 価值については末だ明らかではない9，本実験のように， 粗飼料源として蒸堷処理したブナやコナラのみを与えて， 牛を長期間飼育できるのかどうかを知るためには，牛を 用いて実用条件での長期間の飼養試験を行ない検討する 必要がある。

蒸煮好理したブナとコナラの栄養価（表 4）は，蒸煮 処理シラカンバの TDN 含量（乾物中 $57-65 \%{ }^{7,9)}$ ) よ りも低かった，蒸者処理の温度を高め，時間を長くする ことで,ブナとコナラの消化率がさらに高まるかるしれ ない，しかし，処理条件を高めると，木材中の酰酸やフ 
ルフラールの量が多くなるが，䣷酸は蒸炎処理の間に揮 発し，フルフラールは反㬅家畜のエネルギー源となると は考えられず，それらの生成量が多くなることは好まし くない吕，本夹験での処理条件以上で蒸帛処理を行ない， さらに栄養価の向上を期待する場合には，酢酸やフルフ ラールの生成量を考虑にいれることが必要である。

本研究は，農林水産技術会議による大型別枠研究「バ イオマス変換計画（BCP-85-IV-1-5)」の一部として寒 施したものである。

\section{謝辞}

本実験を遂行するにあたり，農林水産省音珄試験場の 由野良衛，小池豊実の両元技官，椎津三郎，日井房子， 加藤聖哲，鈴木茂雄，井上和明，入江 衞の各技官に御 協力をいただきました。また，栄盖部長針生程吉氏には 御校閲していただきました，各位に感謝します。

\section{文献}

1) Bender, F., D.P. Heaney and A. Bowden, For. Prod. J., 20 : 36-41. 1970.

2) Heaney, D.P. and F. Bender, For. Prod. J., 20: 98102. 1970.

3) AL-Rabbat, M.F. and D.P. Heaney, Can. J. Anim. Sci., $58:$ 443-451. 1978.

4) Sharma, H.R., N.E. Forsberg and W. Guentek, Can. J. Anim. Sci., 59 : 303-312. 1979.

5) Sharma, H.R., W. Guenter, T.J. Devlin, J.R.
Ingalls and M. Mc Daniel, Can. J. Anim. Sci, 60 : 99-106. 1980.

6) Fisher, L.J., Can. J. Anim. Sci, 60:379-384. 1980.

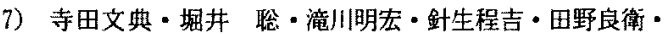

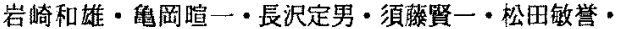
志水一允・棚橋光彦・樋口隆昌, 畜試研報，44:55-59. 1986.

8）寺田文典 - 由野良衛 - 岩㱦和雄 - 猃生程吉 - 伊藤稳 -

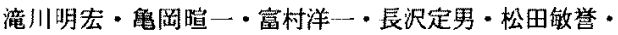
須藤賢一・志水一允，畜試研報，44:97-101. 1986.

9）寺田文典 - 由野良衛・岩崎和雄 - 伊藤稔 - 滝川明宏・ 長沢定男・須藤賢一・志水一允，畜試研報，46:39-44. 1987.

10）暒川博 - 寺田文典・田野良衛・岩崎和雄・伊藤 稳・

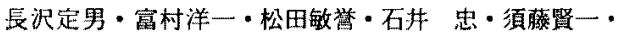
志水一允・大山嘉信, 日畜会報, $58: 101-106.1987$.

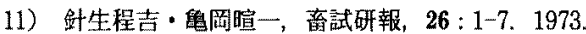

12）農林水産省農林水産技術会議事務局，日本飼養標準 - 肉 用牛（1987 年版）

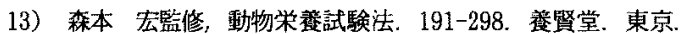
1971.

14) 阿部 亮, 未発表論文

15）阿部 亮・堀井 瞈, 日草誌，20:16-21. 1974.

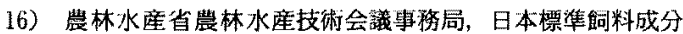
表（1987 年版）

17）田野度衛・寺田文典・針生程吉- 岩崎和雄, 畜試研報, $39:$ 103-105. 1982 .

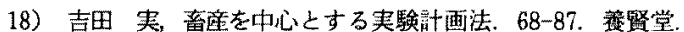
東京. 1975 .

19) Reid, J.T., Proc. Cornell Nutr, Conf. for Feed Manufacturers, Buffalo, N. Y., November, 50-63. 1970.

20) IKumo, H., M. IshidA and A. TAKIGAWA, Jpn. J. Zootech. Sci., 58 : 101-106. 1987. 


\title{
Evaluation of the Nutritive Value of Steamed Japanese Beech and Steamed Japanese Oak by Feeding Experiments and Digestion Trials with Goats
}

\author{
Motohiko Ishida, Fuminori Terada, Tadashi KyuUma, \\ Akihiro TAKIgaWA * Sadao NAgasawa** \\ and Kazumasa SHimizu** \\ National Institute of Animal Industry, Tsukuba \\ Norinkenkyudanchi, Ibaraki-Ken 305 \\ ** Foresty and Forest Products Research Institute, \\ Tsukuba Norinkenkyudanchi, Ibaraki-ken 305
}

Feeding experiments and digestion trials, using goats (average initial body weight $11.0 \mathrm{~kg}$ ), were conducted to evaluate the nutritive value of steamed Japanese beech (Fagus crenata) and steamed Japanese oak (Querues serrata). The steamed wood samples were prepared by steaming bark-removed Japanese beech and Japanese oak at a pressure of $17 \mathrm{~kg} / \mathrm{cm}^{2}$ for $15 \mathrm{~min}$. Four goats were allotted to three treatment diets, descriced as follows ; 1) The diet containing $48 \%$ (dry matter basis) Italian ryegrass hay, 2) The diet containing 45\% steamed Japanese beech and 3) The diet containing 47\% steamed Japanese oak. Feeding experiments were conducted for 70 days. Equal amounts of each diet per metabolic body size was fed to the goats during the experiments. After the feeding experiments, digestion trials were conducted by means of the total collection method. In the feeding experiments, dry matter intake, daily gain and ratio of total digestible nutrient (TDN) intake to the body weight gain in the goats fed the three diets were not significantly different. By using digestion trials data, the TDN content, calculated by difference, of steamed Japanese beech and steamed Japanese oak were estimated to be $43 \%$ and $47 \%$ (dry matter basis), respectively. It was concluded that the dietary energy value of the steamed Japanese beech and the steamed Japanese oak for ruminants were nearly equal to that of rice straw and wild grass, respectively.

Jpn. J. Zootech. Sci., 61(2) : 150-156, 1990

Key words : steamed wood, Japanese beech, Japanese oak, nutritive value, feeding experiment

* Present address : Hokkaido National Agricultural Experiment Station, Sapporo-shi 004 